\section{Pengembangan Assesmen Autentik Berbasis Proyek pada Mata Kuliah Biologi Terapan Melalui Model Pembelajaran Kooperatif Tipe Group Investigation}

\author{
Sri Mukminati Nur \\ Yusniar Rasjid
}

Abstrak. Penelitian ini bertujuan (i) Untuk mengetahui tahapan pengembangan perangkat berbasis proyek pada mata kuliah biologi terapan melalui model pembelajaran kooperatif tipe group investigation; (ii) Untuk mengetahui kualitas perangkat penilaian proyek pada mata kuliah biologi terapan melalui model pembelajaran kooperatif tipe group investigation ditinjau dari validitas dan reliabilitas ditinjau dari kevalidan, reliabilitas, kepraktisan, taraf kesukaran dan daya beda. Penelitian ini adalah pengembangan perangkat dengan menggunakan model riset pengembangan tipe formatif research. Pada penelitian menggunakan satu kelas sebagai subjek penelitian dan satu kelas ujicoba small group pada mahasiswa semester VI mata kuliah biologi terapan semester genap tahun ajaran 2017/2018. Hasil penelitian menunjukkan (i) Pengembangan perangkat assesmen autentik dengan muenggunakan model Plomp yang terdiri dari 5 fase yaitu 1) fase awal; 2) fase perancangan; 3) fase kontruksi; 4) fase tes dan evaluasi; 5) fase implementasi dihasilkan perangkat penilaian yang: (ii) Valid yang dibuktikan dengan adanya koefisien korelasi dari perangkat penilaian kognitif, penilaian psikomotorik, dan penilaian afektif lebih besar dari 0,35 dan nilai signifikansi lebih kecil dari taraf signifikansi 5\%. Reliabel, berdasarkan hasil uji reliabilitas secara empirik dengan menggunakan rumus Alpha Cronbach diperoleh nilai koefisien korelasi perangkat penilaian kognitif, penilaian psikomotorik, dan penilaian afektif secara keseluruhan lebih besar dari 0,76. Objektif, analisis uji objektifitas dengan menggunakan rumus ANAVA terhadap perangkat penilaian kognitif, penilaian psikomotorik, dan penilaian afektif secara keseluruhan diperoleh hasil signifikansi dari observer lebih besar dari taraf signifikansi 5\% yang berarti bahwa tidak terjadi variasi penilaian yang dilakukan oleh ketiga observer. Praktis, analisis uji coba kepraktisan perangkat assesmen autentik memiliki kevalidan 4,05 dengan kategori sangat valid. Sedangkan pada data hasil pengamatan para observer didapatkan nilai keterlaksanaan $\left(T_{L}\right)$ sebesar 3,64 dengan kategori sebagian besar terlaksana.

Kata Kunci: asessmen autentik pembelajaran berbasis proyek, pembelajaran kooperatif tipe group investigation.

\section{Pendahuluan}

Asessmen autentik adalah penilaian hasil belajar yang dilakukan secara komprehensif berkenaan dengan seluruh aktivitas pembelajaran, meliputi proses dan hasil belajar sehingga seluruh usaha peserta didik yang telah dilakukannya mendapat penilaian. Asesmen autentik menuntut peserta didik untuk berunjuk kerja dalam situasi yang konkret dan sekaligus bermakna (Ovianti, 2013). Assesmen autentik dalam penelitian ini diterapkan untuk mengukur keterampilan dalam mengkaji konsep biologi dalam bidang pengolahan makanan dengan pembelajaran berbasis proyek melalui model pembelajaran Group Investigation. Penilaian berbasis proyek dapat meningkatkan tingkat berpikir mahasiswa karena apa yang mahasiswa pelajari erat kaitannya dengan kehidupan mereka seharihari, sehingga dosen dapat menilai tingkat yang mahasiswa pelajari erat kaitannya dengan kehidupan mereka seharihari, sehingga dosen dapat menilai tingkat penguasaan dan

\section{Biology Teaching and Learning}

p-ISSN 2621 - 5527

e-ISSN 2621 - 5535

Abstract. This study aims (i) to find out the stages of project-based device development in applied biology courses through cooperative learning models type group investigation; (ii) To find out the quality of project appraisal devices in applied biology courses through cooperative learning models group

investigation in terms of validity and reliability in terms of validity, reliability, practicality, level of difficulty and power difference. This research is the development of devices using formative research type development research models. In the study using one class as the

research subject and one small group trial class for the sixth semester students in the applied biology semester even the 2017/2018 academic year. The results of the study show (i) Development of authentic assessment tools using the

Plomp model which consists of 5 phases namely 1) the initial phase; 2) design phase; 3) construction phase; 4) the test and evaluation phase; 5) the implementation phase is produced by the appraisal device which: (ii) is valid as evidenced by the existence of a correlation coefficient from the cognitive assessment tool, psychomotor assessment, and affective assessment greater than

0.35 and a significance value smaller than the 5\% significance level. Reliable, based on the results of empirical reliability test using Cronbach Alpha formula obtained the value of the correlation coefficient of cognitive

assessment devices, psychomotor assessment, and overall affective assessment greater than 0.76. Objective, objectivity test analysis using ANAVA formula for cognitive appraisal, psychomotor assessment, and overall affective assessment obtained the results of the significance of the observer greater than the 5\% significance level which means that no variation in the assessment carried out by the three observers. Practically, an analysis of the practicality of the authentic assessment device has a validity of 4.05 with a very valid category. Whereas in the data from

observers' observations, the value of implementation (TL) was 3.64 with the category mostly implemented.

Keywords: project-based authentic asessmen, cooperative learning model type group investigation.

Sri Mukminati Nur

STKIP Pembangunan Indonesia Makassar

Yusniar Rasjid

STKIP Pembangunan Indonesia Makassar 
prestasi mahasiswa yang sebenarnya tanpa adanya rekayasa, perkiraan, dan prediksi penilaian hasil belajar. Dosen dapat menilai mahasiswa secara individu maupun kelompok, dan sikap mahasiswa terhadap proses pembelajaran juga dapat lebih terpantau. Hasil penelitian Novianty (2012), menunjukkan bahwa perangkat penilaian proyek memenuhi kriteria valid, praktis dan efektif sehingga layak digunakan sebagai bagian perangkat penilaian untuk menilai kegiatan praktikum di laboratorium. Dengan demikian, penggunaan perangkat penilaian proyek sangat dibutuhkan dalam pembelajaran, guna meningkatkan sistem penilaian yang dapat mengukur tingkat kemajuan belajar mahasiswa

Model pembelajaran kooperatif tipe group investigation adalah model pembelajaran kooperatif yang lebih menekankan pada pilihan dan kontrol peserta didik dari pada penerapkan teknik-teknik pengajaran di ruang kelas. Mahasiswa ditempatkan dalam kelompok-kelompok kecil. Penggunaan model pembelajaran kooperatif tipe group investigation dalam penelitian ini karena dalam assesmen autentik berbasis proyek, mahasiswa akan melakukan investigasi dan terlibat dalam aktivitas-aktivitas berfikir tingkat tinggi, seperti membuat sintesis, ringkasan, hipotesis, kesimpulan, dan menyajikan laporan akhir sehingga membutuhkan kerjasama antar mahasiswa.

\section{Masalah Penelitian}

1. Bagaimana mengembangkan perangkat asessmen berbasis proyek pada mata kuliah biologi terapan melalui model pembelajaran kooperatif tipe group investigation?

2. Bagaimana kualitas perangkat penilaian proyek mata kuliah biologi terapan melalui model pembelajaran kooperatif tipe group investigation ditinjau dari validitas dan reliabilitas?

\section{Fokus Penelitian}

1. Untuk mengembangkan perangkat assesmen berbasis proyek pada mata kuliah biologi terapan melalui model pembelajaran kooperatif tipe group investigation.

2. Untuk mengetahui kualitas perangkat penilaian proyek pada mata kuliah biologi terapan melalui model pembelajaran kooperatif tipe group investigation ditinjau dari validitas dan reliabilitas.

\section{Metode Penelitian}

Jenis penelitian ini adalah penelitian \& pengembangan (research \& development) dengan menggunakan metode riset pengembangan tipe formative research dengan menghasilkan perangkat penilaian proyek melalui model pembelajaran group investigation. Penelitian ini dilaksanakan di kampus STKIP-PI Makassar dan subjek penelitiannya adalah mahasiswa kelas VI.C pada semester genap tahun pelajaran 2017/2018 sebanyak 23 orang. 


\section{Analisis Data}

\section{Analisis Data Kevalidan}

Data hasil validasi ahli dianalisis dengan mempertimbangkan penilaian, masukan, komentar, dan saran-saran validator. Relevansi kedua pakar secara menyeluruh merupakan validitas isi Gregory yaitu berupa koefisien validitas isi. Koefisien validitas isi dihitung berdasar rumus sebagai berikut (Ruslan, 2009).

$$
\text { Validitas isi }=\frac{D}{(A+B+C+D)}
$$

Berikut adalah model kesepakatan antar penilai untuk validitas isi:

Tabel 1. Model Kesepakatan antar Dua Pakar

\begin{tabular}{|c|c|c|c|}
\hline & & \multicolumn{2}{|c|}{ Validator I } \\
\hline & & $\begin{array}{c}\text { Tidak relevan } \\
\text { Skor (1 - 2) }\end{array}$ & $\begin{array}{c}\text { Relevan } \\
\text { Skor (3 - 4) }\end{array}$ \\
\hline \multirow{2}{*}{$\begin{array}{c}\text { Validator } \\
\text { II }\end{array}$} & $\begin{array}{c}\text { Tidak relevan Skor } \\
(1-2)\end{array}$ & $\mathrm{A}$ & $\mathrm{B}$ \\
\cline { 2 - 4 } & $\begin{array}{c}\text { Relevan } \\
\text { Skor (3-4) }\end{array}$ & $\mathrm{C}$ & $\mathrm{D}$ \\
\hline
\end{tabular}

Sumber: (Gregory dalam Ruslan, 2009)

\section{Analisis Data Keandalan (Reliabilitas)}

Keandalan secara empirik dengan menggunakan uji keandalan koefisien Alpha Crombach terhadap data yang diperoleh dari proses uji coba dengan menggunakan software SPSS. Semakin besar koefisien korelasi yang diperoleh maka akan semakin tinggi tingkat keandalan instrumen tersebut.

Dalam pemberian interpretasi terhadap koefisien reliabilitas instrumen $(r)$ pada umumnya digunakan patokan sebagai berikut:

a. Apabila $r \geq 0,70$ berarti instrumen yang diuji reliabilitasnya dinyatakan telah memiliki reliabilitas yang tinggi (= reliabel).

b. Apabila $r<0,70$ berarti instrumen yang diuji reliabilitasnya dinyatakan belum memiliki reliabilitas yang tinggi (= un-reliabel).

\section{Hasil Penelitian}

1) Validasi

a. Hasil Analisis Validitas Penuntun Pengembangan Perangkat Assesmen Autentik Berbasis Proyek.

Tabel 2. Hasil Penilaian/Validasi Penuntun Pengembangan Perangkat Assesmen Autentik Berbasis Proyek

\begin{tabular}{|l|c|c|}
\hline \multicolumn{1}{|c|}{ Aspek penilaian } & $\overline{\boldsymbol{x}}$ & Ket. \\
\hline Format buku penuntun & 4,67 & Sangat Valid \\
Isi Penuntun & 4,67 & Sangat Valid \\
Bahasa & 4,28 & Valid \\
\hline \multicolumn{1}{|c|}{ Rata-rata penilaian total } & 4,49 & Sangat Valid \\
\hline
\end{tabular}

Hasil analisis yang di tunjukkan pada tabel 2 dapat dijelaskan sebagai berikut:

1. Nilai rata-rata kevalidan penuntun untuk aspek format buku penuntun adalah $\bar{x}=.4,67$ dinyatakan dalam kategori "sangat valid" $(4,5 \leq \bar{x} \leq 5,0)$.

2. Nilai rata-rata kevalidan penuntun untuk aspek isi penuntun adalah $\bar{x}=4,67$, dinyatakan dalam kategori "sangat valid" $(4,5 \leq \bar{x} \leq 5,0)$. 
3. Nilai rata-rata kevalidan penuntun untuk aspek bahasa adalah $\bar{x}=4,28$ dinyatakan dalam kategori "valid" $(3,5 \leq \bar{x} \leq 4,5)$.

Berdasarkan uraian hasil analisis diatas, nilai rata-rata total kevalidan penuntun adalah $\bar{x}=$ 4,49 dari skor ideal 5 sesuai kriteria kevalidan, nilai ini sangat valid" $(4,5 \leq \bar{x} \leq 5,0)$. Jadi ditinjau keseluruhan aspek, maka penuntun dinyatakan memenuhi kriteria kevalidan.

b. Hasil analisis validitas Rencana Pelaksanaan Pembelajaran Pengembangan Assesmen autentik berbasis proyek.

Tabel 3. Hasil Penilaian/Validasi RPP Pengembangan Perangkat Assesmen Autentik Berbasis Proyek

\begin{tabular}{|c|l|c|c|}
\hline No & \multicolumn{1}{|c|}{ Aspek penilaian } & $\overline{\boldsymbol{x}}$ & Ket. \\
\hline 1. & Kompetensi Dasar & 4,67 & Sangat Valid \\
2. & Indikator Pencapaian Kompetensi Dasar & 4,47 & Valid \\
3. & Isi dan kegiatan Pembelajaran & 4,50 & Sangat Valid \\
4. & Bahasa & 4,56 & Sangat Valid \\
5. & Waktu & 4,83 & Sangat Valid \\
6. & Penutup & 4,50 & Sangat Valid \\
\hline & Rata-rata penilaian total & 4,59 & Sangat Valid \\
\hline
\end{tabular}

Hasil analisis yang ditunjukkan pada tabel diatas dapat dijelaskan sebagai berikut:

1. Nilai rata-rata kevalidan RPP untuk aspek kejelasan kompetensi dasar adalah $\bar{x}=.4,67$ dinyatakan dalam kategori "sangat valid" $(4,5 \leq \bar{x} \leq 5,0)$.

2. Nilai rata-rata kevalidan RPP untuk aspek indikator pencapaian kompetensi dasar adalah $\bar{x}=$ 4,47 , dinyatakan dalam kategori "sangat valid" $(4,5 \leq \bar{x} \leq 5,0)$.

3. Nilai rata-rata kevalidan RPP untuk aspek isi dan kegiatan pembelajaran adalah $\bar{x}=4,50$ dinyatakan dalam kategori "sangat valid" $(4,5 \leq \bar{x} \leq 5,0)$.

4. Nilai rata-rata kevalidan RPP untuk aspek bahasa adalah $\bar{x}=4,56$ dinyatakan dalam kategori 'sangat valid' $(4,5 \leq \bar{x} \leq 5,0)$

5. Nilai rata-rata kevalidan RPP untuk aspek waktu adalah $\bar{x}=4,83$ dinyatakan dalam kategori" sangat valid" $(4.5 \leq \bar{x} \leq 5,0)$

6. Nilai rata-rata kevalidan RPP untuk aspek penutup adalah $\bar{x}=4,50$ dinyatakan dalam kategori "sangat valid" $(4,5 \leq \bar{x} \leq 5,0)$

Berdasarkan uraian hasil analisis diatas, nilai rata-rata total kevalidan rpp adalah $\bar{x}=4,59$ dari skor ideal 5 sesuai kriteria kevalidan, nilai ini sangat valid" $(4,5 \leq \bar{x} \leq 5,0)$ Jadi ditinjau keseluruhan aspek, maka RPS dan SAP dinyatakan memenuhi kriteria kevalidan.

\section{c. Hasil Analisis Validitas Instrumen Penilaian Kognitif Pengembangan Assesmen Autentik Berbasis Proyek.}

Tabel 4. Hasil Penilaian/Validasi Instrumen Penilaian Kognitif Pengembangan Perangkat Assesmen Autentik Berbasis Proyek

\begin{tabular}{|c|l|c|c|}
\hline No & Aspek penilaian & $\overline{\boldsymbol{x}}$ & Ket. \\
\hline 1. & Substansi & 4,16 & Valid \\
2. & Konstruksi & 4,08 & Valid \\
3. & Bahasa & 4,08 & Valid \\
\hline & Rata-rata penilaian total & 4,10 & Valid \\
\hline
\end{tabular}

Berdasarkan tabel 4 Hasil Penilaian/Validasi Penilaian Kognitif Pengembangan Perangkat Penilaian Assesmen Autentik Berbasis Proyek sebagai berikut:

1. Nilai rata-rata kevalidan instrumen penilaian kognitif untuk aspek substansi adalah $\bar{x}=4,16$ dinyatakan dalam kategori "valid" $(3,5 \leq \bar{x} \leq 4,5)$.

2. Nilai rata-rata kevalidan instrumen penilaian kognitif untuk aspek bahasa adalah $\bar{x}=4,08$ dinyatakan dalam kategori" valid" $(3,5 \leq \bar{x} \leq 4,5)$ 
Pengembangan Assesmen Autentik Berbasis Proyek pada Mata Kuliah Biologi

Terapan Melalui Model Pembelajaran Kooperatif Tipe Group Investigation (hlm. 88-100)

p-ISSN 2621-5527

e-ISSN2621-5535

3. Nilai rata-rata kevalidan instrumen penilaian kognitif untuk aspek isi adalah $\bar{x}=4,08$ dinyatakan dalam kategori "valid" $(3,5 \leq \bar{x} \leq 4,5)$

Berdasarkan uraian hasil analisis diatas, nilai rata-rata total kevalidan instrumen penilaian kognitif adalah $\bar{x}=4,10$ dari skor ideal 5 sesuai kriteria kevalidan nilai ini valid," $(3,5 \leq \bar{x} \leq 4,5)$. Jadi ditinjau keseluruhan aspek, maka instrumen penilaian kognitif dinyatakan memenuhi kriteria kevalidan.

\section{d. Hasil Analisis Validitas Instrumen Penilaian Afektif Pengembangan Assesmen Autentik Berbasis Proyek.}

Tabel 5. Hasil Penilaian/Validasi Instrumen Penilaian Afektif Pengembangan Perangkat Assesmen Autentik Berbasis Proyek

\begin{tabular}{|c|l|c|c|}
\hline No & Aspek penilaian & $\overline{\boldsymbol{x}}$ & Ket. \\
\hline 1. & Substansi & 4,00 & Valid \\
2. & Konstruksi & 4,08 & Valid \\
3. & Bahasa & 4,16 & Valid \\
\hline & Rata-rata penilaian total & 4,08 & Valid \\
\hline
\end{tabular}

Berdasarkan tabel 5 Hasil Penilaian/Validasi Penilaian Afektif Pengembangan Perangkat Penilaian Assesmen Autentik Berbasis Proyek sebagai berikut:

1. Nilai rata-rata kevalidan instrumen penilaian afektif untuk aspek substansi adalah $\bar{x}=4,00$ dinyatakan dalam kategori 'valid' $(3,5 \leq \bar{x} \leq 4,5)$

2. Nilai rata-rata kevalidan instrumen penilaian afektif untuk aspek bahasa adalah $\bar{x}=4,08$ dinyatakan dalam kategori" valid" $(3,5 \leq \bar{x} \leq 4,5)$

3. Nilai rata-rata kevalidan instrumen penilaian afektif untuk aspek isi adalah $\bar{x}=4,16$ dinyatakan dalam kategori "valid" $(3,5 \leq \bar{x} \leq 4,5)$

Berdasarkan uraian hasil analisis diatas, nilai rata-rata total kevalidan instrumen penilaian afektif adalah $\bar{x}=4,08$ dari skor ideal 5 sesuai kriteria kevalidan, nilai ini valid" $(3,5 \leq \bar{x} \leq 4,5)$. Jadi ditinjau keseluruhan aspek, maka instrumen penilaian afektif dinyatakan memenuhi kriteria kevalidan.

e. Hasil analisis validitas instrumen penilaian psikomotorik Pengembangan Assesmen autentik berbasis proyek.

Tabel 6. Hasil Penilaian/Validasi Instrumen Penilaian Psikomotorik Pengembangan Perangkat Assesmen Autentik Berbasis Proyek

\begin{tabular}{|c|l|c|c|}
\hline No & \multicolumn{1}{|c|}{ Aspek penilaian } & $\overline{\boldsymbol{x}}$ & Ket \\
\hline 1. & Substansi & 4,33 & Valid \\
\hline 2. & Konstruksi & 4,24 & Valid \\
\hline 3. & Bahasa & 4,24 & Valid \\
\hline & Rata-rata penilaian total & 4,26 & Valid \\
\hline
\end{tabular}

Berdasarkan tabel 6 hasil penilaian/validasi penilaian psikomotorik pengembangan perangkat penilaian assesmen autentik berbasis proyek sebagai berikut:

1. Nilai rata-rata kevalidan instrumen penilaian psikomotorik untuk aspek substansi adalah $\bar{x}=$ 4,33 dinyatakan dalam kategori 'valid' $(3,5 \leq \bar{x} \leq 4,5)$.

2. Nilai rata-rata kevalidan instrumen penilaian psikomotorik untuk aspek bahasa adalah $\bar{x}=$ 4,24 dinyatakan dalam kategori" valid" $(3,5 \leq \bar{x} \leq 4,5)$.

3. Nilai rata-rata kevalidan instrumen penilaian psikomotorik untuk aspek isi adalah $\bar{x}=4,24$ dinyatakan dalam kategori "valid" $(3,5 \leq \bar{x} \leq 4,5)$.

Berdasarkan uraian hasil analisis diatas, nilai rata-rata total kevalidan instrumen penilaian psikomotorik adalah $\bar{x}=4,26$ dari skor ideal 5 sesuai kriteria kevalidan (, nilai ini valid" $(3,5 \leq \bar{x} \leq$ 4,5 ). Jadi ditinjau keseluruhan aspek, maka instrumen penilaian psikomotorik dinyatakan memenuhi kriteria kevalidan. 


\section{2) Kegiatan Uji Coba Lapangan}

\section{a. Hasil uji kesahihan perangkat assesmen autentik berbasis proyek.}

Pengujian terhadap validitas item berdasarkan hasil uji coba tes dilakukan dengan menggunakan program SPSS dengan analisis Correlate Bivariate Pearson. Hasil analisis yang diperoleh dijelaskan sebagai berikut:

1) Uji kevalidan penilaian kognitif

a) Penilaian kognitif pertemuan 1

Hasil analisis correlate bivariate pearson penilaian kognitif pertemuan 1 secara lengkap disajikan pada lampiran. Berdasarkan hasil analisis validitas item terhadap instrumen penilaian kognitif dengan menggunakan analisis Correlate Bivariate Pearson diperoleh nilai korelasi untuk butir soal nomor 1, 2, 3, 4 dan 5 secara berturut-turut adalah 0,832; 0,745; 0,729; dan 0,811 lebih besar dari 0,3. Menurut kriteria Cronbach standar minimal koefisien korelasi sebagai acuan validitas adalah 0,35 , maka seluruh nilai korelasi untuk butir soal nomor 1, 2, 3, 4, dan 5 valid.

Demikian juga jika digunakan acuan bahwa untuk signifikansi 0,05 yang digunakan, diperoleh bahwa untuk butir soal nomor $1,2,3$, 4, dan 5 secara berturut-turut 0,$001 ; 0,005$; 0,$007 ; 0,001 ; 0,003$ lebih kecil dari 0,05. Secara keseluruhan nilai signifikansi setiap item soal lebih kecil dari 0,05 sehingga dapat dikatakan bahwa butir-butir soal pada instrumen penilaian kognitif pertemuan 1 valid secara keseluruhan.

b) Penilaian kognitif pertemuan 2

Hasil analisis correlate bivariate pearson penilaian kognitif pertemuan 2 secara lengkap disajikan pada lampiran. Berdasarkan hasil analisis validitas item terhadap instrumen penilaian kognitif dengan menggunakan analisis Correlate Bivariate Pearson diperoleh nilai korelasi untuk butir soal nomor 1, 2, 3, 4 dan 5 secara berturut-turut adalah 0,868; 0,822; 0,629; 0,802 dan 0,832 lebih besar dari 0,3. Menurut kriteria Cronbach standar minimal koefisien korelasi sebagai acuan validitas adalah 0,35 , maka seluruh nilai korelasi untuk butir soal nomor 1, 2, 3, 4, dan 5 valid.

Demikian juga jika digunakan acuan bahwa untuk signifikansi 0,05 yang digunakan, diperoleh bahwa untuk butir soal nomor $1,2,3$, 4, dan 5 secara berturut-turut 0,$000 ; 0,001$; 0,$029 ; 0,002 ; 0,001$ lebih kecil dari 0,05. Secara keseluruhan nilai signifikansi setiap item soal lebih kecil dari 0,05 sehingga dapat dikatakan bahwa butir-butir soal pada instrumen penilaian kognitif pertemuan 2 valid secara keseluruhan.

c) Penilaian kognitif pertemuan 3

Hasil analisis correlate bivariate pearson penilaian kognitif pertemuan 3 secara lengkap disajikan pada lampiran. Berdasarkan hasil analisis validitas item terhadap instrumen penilaian kognitif dengan menggunakan analisis Correlate Bivariate Pearson diperoleh nilai korelasi untuk butir soal nomor 1, 2, 3, 4 dan 5 secara berturut-turut adalah 0,918; 0,646; 0,604; 0,938 dan 0,938 lebih besar dari 0,3. Menurut kriteria Cronbach standar minimal koefisien korelasi sebagai acuan validitas adalah 0,35 , maka seluruh nilai korelasi untuk butir soal nomor 1, 2, 3, 4, dan 5 valid.

Demikian juga jika digunakan acuan bahwa untuk signifikansi 0,05 yang digunakan, diperoleh bahwa untuk butir soal nomor $1,2,3$, 4, dan 5 secara berturut-turut 0,000; 0,023; 0,037; 0,000; 0,000 lebih kecil dari 0,05. Secara keseluruhan nilai signifikansi setiap item soal lebih kecil dari 0,05 sehingga dapat dikatakan bahwa butir-butir soal pada instrumen penilaian kognitif pertemuan 3 valid secara keseluruhan.

2) Uji kevalidan penilaian afektif

Hasil analisis correlate bivariate pearson penilaian afektif secara lengkap disajikan pada lampiran. Berdasarkan hasil analisis validitas terhadap instrumen penilaian afektif dengan menggunakan analisis Correlate Bivariate Pearson diperoleh nilai korelasi untuk setiap pertemuan 1, 2, dan 3 secara berturut-turut adalah 0,910; 0,935; dan 0,801 lebih besar dari 0,3. Menurut kriteria Cronbach standar minimal koefisien korelasi sebagai acuan validiats adalah 0,35, maka seluruh nilai korelasi untuk pertemuan 1, 2 dan 3 valid. 
Demikian juga jika digunakan acuan bahwa untuk signifikansi 0,05 yang digunakan, diperoleh bahwa untuk pertemuan 1, 2, dan 3 secara berturut-turut 0,000;0,000 dan 0,002 lebih kecil dari 0,05. Secara keseluruhan nilai signifikansi setiap pertemuan lebih kecil dari 0,05 sehingga dapat dikatakan bahwa penilaian afektif beberapa pertemuan valid secara keseluruhan.

3) Uji kevalidan penilaian psikomotorik.

Hasil analisis correlate bivariate pearson penilaian psikomotorik secara lengkap disajikan pada lampiran. Berdasarkan hasil analisis validitas terhadap instrumen penilaian psikomotorik dengan menggunakan analisis Correlate Bivariate Pearson diperoleh nilai korelasi untuk setiap pertemuan 1, 2, dan 3 secara berturut-turut adalah 0,900; 0,678; dan 0,803 lebih besar dari 0,3. Menurut kriteria Cronbach standar minimal koefisien korelasi sebagai acuan validiats adalah 0,35, maka seluruh nilai korelasi untuk pertemuan 1,2 dan 3 valid.

Demikian juga jika digunakan acuan bahwa untuk signifikansi 0,05 yang digunakan, diperoleh bahwa untuk pertemuan 1,2 , dan 3 secara berturut-turut 0,$000 ; 0,015$ dan 0,002 lebih kecil dari 0,05. Secara keseluruhan nilai signifikansi setiap pertemuan lebih kecil dari 0,05 sehingga dapat dikatakan bahwa penilaian psikomotorik beberapa pertemuan valid secara keseluruhan.

\section{b. Hasil uji kereliabelan perangkat assesmen autentik berbasis proyek.}

Data yang diperoleh dari proses uji coba penilaian setelah diuji validitas kemudian dilakukan uji kereliabelan. Pengujian kereliabelan secara empirik menggunakan uji kereliabelan koefisien Alpha Cronbach terhadap perangkat assesmen autentik dengan menggunakan SPSS. Hasil analisis untuk pengujian koefisien kereliabelan Alpha Cronbach dikemukakan sebagai berikut:

1) Uji koefisien kereliabelan Alpha Cronbach penilaian kognitif

a) Uji koefisien kereliabelan penilaian kognitif pertemuan 1.

Berdasarkan hasil analisis yang dilakukan dengan menggunakan SPSS, maka diperoleh hasil analisis untuk pengujian koefisien Alpha Cronbach pada penilaian kognitif pertemuan 1 sebesar 0,798. Menurut Sudijino, suatu tes dikatakan memiliki tingkat kereliabelan yang tinggi apabila koefisien reliabilitasnya sama dengan atau lebih besar dari 0,70. Dari hasil SPSS koefisien korelasi penilaian kognitif pertemuan 1 sebesar 0,798 lebih besar dari 0,70, maka dapat dikatakan bahwa penilaian kognitif pertemuan 1 adalah reliabel.

b) Uji koefisien kereliabelan penilaian kognitif pertemuan 2 .

Berdasarkan hasil analisis yang dilakukan dengan menggunakan SPSS, maka diperoleh hasil analisis untuk pengujian koefisien Alpha Cronbach pada penilaian kognitif pertemuan 2 sebesar 0,804. Menurut Sudijino, suatu tes dikatakan memiliki tingkat reliabilitas yang tinggi apabila koefisien reliabilitasnya sama dengan atau lebih besar dari 0,70. Dari hasil SPSS koefisien korelasi penilaian kognitif pertemuan 2 sebesar 0,804 lebih besar dari 0,70, maka dapat dikatakan bahwa penilaian kognitif pertemuan 2 adalah reliabel.

c) Uji koefisien kereliabelan penilaian kognitif pertemuan 3 .

Berdasarkan hasil analisis yang dilakukan dengan menggunakan SPSS, maka diperoleh hasil analisis untuk pengujian koefisien Alpha Cronbach pada penilaian kognitif pertemuan 3 sebesar 0,811. Menurut Sudijino, suatu tes dikatakan memiliki tingkat reliabilitas yang tinggi apabila koefisien reliabilitasnya sama dengan atau lebih besar dari 0,70. Dari hasil SPSS koefisien korelasi penilaian kognitif pertemuan 3 sebesar 0,811 lebih besar dari 0,70, maka dapat dikatakan bahwa penilaian kognitif pertemuan 3 adalah reliabel.

2) Uji koefisien kereliabelan Alpha Cronbach penilaian afektif

Berdasarkan hasil analisis yang dilakukan dengan menggunakan SPSS, maka diperoleh hasil analisis untuk pengujian koefisien Alpha Cronbach pada penilaian afektif sebesar 0,858. Menurut Sudijino, suatu tes dikatakan memiliki tingkat kereliabelan yang tinggi apabila koefisien reliabilitasnya sama dengan atau lebih besar dari 0,70. Dari hasil SPSS koefisien korelasi penilaian afektif sebesar 0,858 lebih besar dari 0,70, maka dapat dikatakan bahwa penilaian afektif adalah reliabel. 
3) Uji koefisien kereliabelan Alpha Cronbach penilaian psikomotorik

Berdasarkan hasil analisis yang dilakukan dengan menggunakan SPSS, maka diperoleh hasil analisis untuk pengujian koefisien Alpha Cronbach pada penilaian psikomotorik sebesar 0,707. Menurut Sudijino, suatu tes dikatakan memiliki tingkat kereliabelan yang tinggi apabila koefisien reliabilitasnya sama dengan atau lebih besar dari 0,70. Dari hasil SPSS koefisien korelasi penilaian psikomotorik sebesar 0,707 sama dengan 0,70, maka dapat dikatakan bahwa penilaian psikomotorik adalah reliabel.

\section{c. Hasil uji keobjektifan perangkat assesmen autentik berbasis proyek.}

Uji keobjektifan penilaian autentik berbasis proyek ini dilakukan dengan menggunakan statistik ANAVA dengan melihat hasil yang diperoleh dari observer 1, observer 2, dan observer 3 . Analisis keobjektifan lembar penilaian dilakukan dengan memperhatikan hipotesis yang disesuaikan dengan hasil analisis ANAVA dengan menggunakan taraf signifikansi 5\%. Kriteria pengujiannya dengan membandingkan dengan taraf signifikansi $\alpha=0,05$. Jika sig. $>0,05$, maka $\mathrm{H}_{0}$ diterima dan $\mathrm{H}_{1}$ ditolak, demikian pula sebaliknya. Apabila $\mathrm{H}_{0}$ diterima atau tidak terdapat variasi penilaian yang dilakukan oleh observer, maka lembar penilaian memenuhi kriteria keobjetifan.

1) Uji keobjektifan lembar penilaian kognitif.

Uji keobjektifan lembar penilaian kognitif dilakukan dengan mengajukan hipotesis sebagai berikut:

$\mathrm{H}_{0}$ : Tidak terdapat variasi penilaian yang dilakukan oleh observer.

$\mathrm{H}_{1}$ : Terdapat perbedaan variasi penilaian yang dilakukan oleh observer.

Berdasarkan hasil analisis ANAVA lembar penilaian kognitif, diperoleh nilai signifikansi 0,000 lebih kecil dari signifikansi $5 \%(0,05)$. Hal ini berarti bahwa hipotesis $\mathrm{H}_{0}$ ditolak. Jadi lembar penilaian kognitif belum memenuhi kriteria objektif.

2) Uji keobjektifan lembar penilaian afektif.

Uji keobjektifan lembar penilaian afektif dilakukan dengan mengajukan hipotesis sebagai berikut:

$\mathrm{H}_{0}$ : Tidak terdapat variasi penilaian yang dilakukan oleh observer.

$\mathrm{H}_{1}$ : Terdapat perbedaan variasi penilaian yang dilakukan oleh observer.

Berdasarkan hasil analisis ANAVA lembar penilaian afektif diperoleh nilai signifikansi 0,959 lebih besar dari signifikansi 5\% $(0,05)$. Hal ini berarti bahwa hipotesis $\mathrm{H}_{0}$ diterima yaitu tidak terdapat variasi penilaian yang dilakukan oleh observer dalam penilaian efektif. Jadi lembar penilaian afektif bersifat objektif.

3) Uji keobjektifan lembar penilaian psikomotorik.

Uji keobjektifan lembar penilaian psikomotorik dilakukan dengan mengajukan hipotesis sebagai berikut:

$\mathrm{H}_{0}$ : Tidak terdapat variasi penilaian yang dilakukan oleh observer.

$\mathrm{H}_{1}$ : Terdapat perbedaan variasi penilaian yang dilakukan oleh observer.

Berdasarkan hasil analisis ANAVA lembar penilaian psikomotorik diperoleh nilai signifikansi 0,241 lebih besar dari signifikansi 5\% $(0,05)$. Hal ini berarti bahwa hipotesis $\mathrm{H}_{0}$ diterima yaitu tidak terdapat variasi penilaian yang dilakukan oleh observer dalam penilaian psikomotorik. Jadi lembar penilaian psikomotorik bersifat objektif.

4) Uji keobjektifan lembar penilaian proses kooperatif

Uji keobjektifan lembar penilaian proses kooperatif dilakukan dengan mengajukan hipotesis sebagai berikut:

$\mathrm{H}_{0}$ : Tidak terdapat variasi penilaian yang dilakukan oleh observer.

$\mathrm{H}_{1}$ : Terdapat perbedaan variasi penilaian yang dilakukan oleh observer.

Berdasarkan hasil analisis ANAVA lembar penilaian proses kooperatif diperoleh nilai signifikansi 0,865 lebih besar dari signifikansi 5\% $(0,05)$. Hal ini berarti bahwa hipotesis $\mathrm{H}_{0}$ diterima yaitu tidak terdapat variasi penilaian yang dilakukan oleh observer dalam penilaian proses kooperatif. Jadi lembar penilaian proses kooperatif bersifat objektif.

5) Uji keobjektifan lembar penilaian produk siswa

Uji keobjektifan lembar penilaian produk siswa dilakukan dengan mengajukan hipotesis sebagai berikut: 
$\mathrm{H}_{0}$ : Tidak terdapat variasi penilaian yang dilakukan oleh observer.

$\mathrm{H}_{1}$ : Terdapat perbedaan variasi penilaian yang dilakukan oleh observer.

Berdasarkan hasil analisis ANAVA lembar penilaian produk siswa diperoleh nilai signifikansi 0,604 lebih besar dari signifikansi 5\% (0,05). Hal ini berarti bahwa hipotesis $\mathrm{H}_{0}$ diterima yaitu tidak terdapat variasi penilaian yang dilakukan oleh observer dalam penilaian produk siswa. Jadi lembar penilaian produk siswa bersifat objektif.

\section{d. Hasil Uji Kepraktisan Perangkat Asesmen Autentik Berbasis Proyek}

Hasil yang diperoleh berdasarkan validasi lembar observasi perangkat dan lembar keterlaksanaan sebanyak 3 kali pertemuan. Untuk mengetahui hasil uji kepraktisan perangkat assesmen autentik dapat diperoleh malalui proses validasi oleh 2 validator dan data hasil lembar observasi yang dilakukan oleh observer selama pelaksanaan pembelajaran.

1) Hasil Penilaian Kevalidan Penerapan Perangkat Assesmen Autentikf berdasarkan Para Validator.

Tabel 7. Hasil Penilaian Kevalidan Penerapan Perangkat Assesmen Autentik Berdasarkan Para Validator

\begin{tabular}{|c|l|c|c|}
\hline \multirow{2}{*}{ No } & \multirow{2}{*}{ Aspek Penilaian } & \multicolumn{2}{|c|}{ Validator } \\
\cline { 3 - 4 } & Aspek Petunjuk & 4,33 & $\mathbf{2}$ \\
\hline 1 & Aspek Isi & 3,75 & 4,51 \\
\hline 2 & Aspek Bahasa & 3,66 & 4,00 \\
\hline 3 & & 4,33 \\
\hline
\end{tabular}

Menurut penilaian para validator, diperoleh hasil bahwa perangkat asessmen autentik berbasis proyek yang dikembangkan memiliki kevalidan 4,05. Hal ini dapat disimpulkan bahwa perangkat asessmen autentik berbasis proyek "sangat valid" untuk diterapkan karena berada pada interval $4<\mathrm{V}_{\mathrm{L}}<5$.

2) Hasil Observasi Keterlaksanaan Perangkat Assesmen Autentik Berbasis Proyek

Berdasarkan hasil analisis yang dilakukan, lembar observasi keterlaksanaan perangkat assesmen autentik berbasis proyek diperoleh data dari observasi yang dilakukan oleh observer terhadap pelaksanaan pembelajaran yang disajikan pada Tabel 4.

Tabel 8. Hasil Lembar Observasi Keterlaksanaan Perangkat Assesmen Autentik Berbasis Proyek

\begin{tabular}{|c|c|c|c|c|c|c|c|c|c|c|}
\hline \multirow{3}{*}{ No } & \multirow{3}{*}{ Aspek Pengamatan } & \multicolumn{9}{|c|}{ Pertemuan } \\
\hline & & \multicolumn{3}{|c|}{$\mathbf{O}_{1}$} & \multicolumn{3}{|c|}{$\mathbf{O}_{2}$} & \multicolumn{3}{|c|}{$\mathbf{O}_{3}$} \\
\hline & & 1 & 2 & 3 & 1 & 2 & 3 & 1 & 2 & 3 \\
\hline 1. & $\begin{array}{l}\text { Mempersiapkan siswa untuk menyiapkan diri terhadap penilaian } \\
\text { yang akan dilakukan }\end{array}$ & 3 & 3 & 4 & 3 & 4 & 4 & 3 & 3 & 3 \\
\hline 2. & $\begin{array}{l}\text { Dosen memotivasi siswa, appersepsi dan penyampaian tujuan } \\
\text { pembelajaran serta pentingnya melakukan penilaian }\end{array}$ & 3 & 2 & 3 & 3 & 3 & 4 & 4 & 3 & 3 \\
\hline 3. & Dosen mengorganisasikan siswa ke dalam kelompok & 4 & 4 & 4 & 4 & 4 & 4 & 4 & 4 & 4 \\
\hline 4. & $\begin{array}{l}\text { Dosen menyampaikan strategi pembelajaran serta pokok- pokok } \\
\text { materi secara singkat. }\end{array}$ & 4 & 4 & 4 & 4 & 4 & 4 & 4 & 4 & 4 \\
\hline 5. & $\begin{array}{l}\text { Dosen memberikan kesempatan kepada siswa untuk } \\
\text { mengerjakan lembar kerja dalam penuntun }\end{array}$ & 4 & 4 & 4 & 4 & 4 & 4 & 4 & 4 & 4 \\
\hline 6. & $\begin{array}{l}\text { Observer melakukan penilaian kepada siswa terkait aspek } \\
\text { pengamatan afektif dan psikomotorik }\end{array}$ & 3 & 2 & 4 & 4 & 3 & 4 & 3 & 3 & 3 \\
\hline 7. & $\begin{array}{l}\text { Observer melakukan penilaian proses kooperatif pada saat } \\
\text { pembelajaran berlangsung }\end{array}$ & 3 & 4 & 2 & 3 & 3 & 3 & 4 & 4 & 2 \\
\hline 8. & $\begin{array}{l}\text { Dosen meminta masing-masing kelompok untuk melakukan } \\
\text { presentasi }\end{array}$ & 4 & 4 & 4 & 4 & 4 & 4 & 4 & 4 & 4 \\
\hline 9. & Dosen mengumpulkan hasil kerja siswa secara perseorangan & 4 & 4 & 4 & 4 & 4 & 4 & 4 & 4 & 4 \\
\hline & Rerata & & 3,55 & & & 3,74 & & &, 63 & \\
\hline & Rata - rata $T_{L}$ & & & & & & & & 3,64 & \\
\hline
\end{tabular}


Menurut penilaian para observer, diperoleh hasil bahwa keterlaksanaan perangkat assesmen autentik berbasis proyek ini memiliki nilai keterlaksanaan $\left(\mathrm{T}_{\mathrm{L}}\right)$ sebesar 3,64. hal ini dapat disimpulkan bahwa penerapan perangkat asesmen autentik berbasis proyek "sebagian besar terlaksana" karena berada pada interval $3<\mathrm{T}_{\mathrm{L}}<4$.

\section{Fase Implementasi}

Fase implementasi merupakan tahap penggunaan perangkat yang telah dikembangkan setelah dilakukan ujicoba, tetapi mengingat keterbatasan waktu maka tahap implementasi dilakukan dengan penyebaran penerapan secara terbatas yaitu dengan menyebarkan dan mensosialisasikan pada dosen mata kuliah biologi terapan untuk diimplementasikan secara operasional dalam melaksanakan assesmen autentik berbasis proyek, yang selanjutnya akan dijaring respon dosen untuk refleksi terhadap kelemahan dan kelebihan instrumen yang dikembangkan.

Kelemahan berdasarkan pendapat dosen:

1. Waktu yang digunakan sangat banyak sehingga harus mempunyai waktu-waktu tertentu

2. Tanggungjawab dosen dan resiko membawa mahasiswa belajar di luar sekolah sangat tinggi

3. Rubrik penilaian yang dikembangkan sangat rumit dan banyak sehingga kemungkinan dosen bersangkutan tidak dapat menilai dengan baik tanpa bantuan orang lain.

Kelebihan berdasarkan pendapat dosen:

1. Mahasiswa mempunyai motivasi tinggi jika dibelajarkan langsung dengan alam sehingga mahasiswa akan lebih mudah memahami materi

2. Penggunaan rubrik penilaian yang baik dan terperinci, dosen tidak lagi menilai dengan perkiraan atau prediksi saja.

3. Rubrik penilaian yang dikembangkan tersebut dapat menilai proses belajar dan hasil belajar mahasiswa dengan baik.

\section{Pembahasan}

Dari hasil penelitian ini akan dikemukakan tentang (1) ketercapaian tujuan penelitian, (2) kendala-kendala yang ditemui selama pelaksanaan penelitian dan (3) keterbatasan penelitian. Ketercapaian tujuan penelitian akan dikemukakan sejauh mana tercapainya tujuan penelitian. Tujuan yang ingin dicapai pada penelitian ini adalah untuk memperoleh pengembangan perangkat penilaian autentik berbasis proyek yang memenuhi kriteria valid, reliabel, objektif dan praktis.

1. Validitas

Berdasarkan hasil analisis korelasi, perangkat penilaian kognitif, penilaian psikomotorik, dan penilaian afektif secara keseluruhan telah memenuhi kriteria kevalidan. Hal ini dibuktikan dengan adanya koefisien korelasi dari perangkat penilaian kognitif, penilaian psikomotorik, dan penilaian afektif lebih besar dari 0,35 dimana Cronbach mengemukakan bahwa koofisien berkisar antara 0,35 sampai 0,50 telah dapat memberikan konstribusi yang baik, dan nilai signifikansi lebih kecil dari taraf signifikansi 5\% yang diolah melalui teori korelasi product moment pada software SPSS dan setelah mendapat nilai $r$ hitung kemudian dibandingkan dengan nilai $r$ tabel dengan taraf signifikan $5 \%$.

2. Reliabilitas

Berdasarkan hasil uji reliabilitas secara empirik dengan menggunakan rumus Alpha Cronbach diperoleh nilai koefisien korelasi perangkat penilaian kognitif, penilaian psikomotorik, dan penilaian afektif secara keseluruhan lebih besar dari 0,70. Jadi dapat disimpulkan bahwa instrumen perangkat assesmen autentik berbasis proyek secara keseluruhan telah memenuhi kriteria reliabel. Hal ini dibahas berdasarkan teori yang dikemukakan oleh Sudijono (dalam Sukindar, 2012:56) dalam pemberian interpretasi terhadap koofisien kereliabelan dengan patokan $r_{11}$ lebih atau sama dengan 0,70 berarti tes hasil belajar dinyatakan reliabel dan jika $\mathrm{r}_{11}$ kurang dari 0,70 berarti tes hasil belajar belum terlalu reliabel.

3. Objektivitasi

Berdasarkan hasil analisis uji objektivitas dengan menggunakan rumus ANAVA terhadap perangkat penilaian kognitif, penilaian psikomotorik, dan penilaian afektif secara keseluruhan 
telah dapat dikatakan memenuhi kriteria keobjektifan. Hal ini terbukti dari hasil signifikansi dari observer lebih besar dari taraf signifikansi 5\% yang berarti bahwa tidak terjadi variasi penilaian yang dilakukan oleh ketiga observer. Hal ini sesuai dengan teori dan harapan bahwa perangkat dikatakan objektif jika signifikansi $>5 \%$, maka $\mathrm{H}_{0}$ diterima dan jika signifikansinya < $5 \%$ maka $\mathrm{H}_{0}$ ditolak. Hipotesis yang diharapkan dalam hal ini adalah tidak terdapatnya variasi penilaian yang dilakukan oleh observer sehingga dengan demikian maka kriteria objektivitas untuk perangkat assesmen autentik yang dikembangkan terpenuhi.

4. Kepraktisan

Berdasarkan hasil validasi yang dilakukan oleh para validator tentang perangkat assesmen autentik yang dikembangkan dinyatakan bahwa perangkat assesmen autentik yang dibuat dapat digunakan. Demikian pula berdasarkan hasil observasi oleh para 3 observer yaitu diperoleh bahwa perangkat assesmen autentik yang telah divalidasi secara teoritis dapat digunakan dengan baik dengan nilai 3,64 dan masuk dalam kategori kevalidan sebagian besar dapat terlaksana $(3<\mathrm{T}<4)$.

Pelaksanaan uji coba perangkat assesmen autentik mengalami beberapa kendala, yaitu:

1. Waktu yang digunakan sangat banyak sehingga harus mempunyai waktu-waktu tertentu sesuai dengan teori yang dikemukakan oleh Sa'dijah (2009: 95) bahwa salah satu kelemahan assesmen autentik adalah waku yang relatif lama. Hal ini juga merupakan salah satu faktor utama dalam peneliian pengembangan assesmen ini.

2. Penilaian kurang relevan yang disebabkan rubrik penilaian yang dikembangkan sangat rumit dan banyak sehingga kemungkinan dosen bersangkutan tidak dapat menilai dengan baik sesuai dengan teori yang dikemukakan oleh Sa'dijah (2009: 95) bahwa terdapat kecendrungan dosen bersikap subjektif dalam menilai sehingga dikhawatirkan penilaian kurang relevan.

Kemudian kendala yang ditemukan pada fase implementasi adalah dosen tidak mempunyai banyak waktu untuk melakukan penerapan perangkat tersebut karena dosen masingmasing sibuk menghadapi persiapan ujian siswa yang sudah dekat, sehingga implementasi ini digantikan dengan sosialisasi beberapa dosen khususnya dosen pendidikan biologi yang kemudian diminta pendapat dosen tentang kelemahan dan kelebihan pengembangan perangkat assesmen autentik berbasis proyek tersebut.

Dalam penelitian pengembangan assesmen autentik berbasis proyek ini terdapat beberapa keterbatasan dalam pelaksanaannya. Meskipun demikian penelitian tetap dilaksanakan dan berjalan sesuai dengan waktu yang ada. Beberapa keterbatasan-keterbatasan antara lain:

1. Relevansi materi, kesesuaian materi dan mata pelajaran harus sesuai dengan jenis assesmen yang digunakan sesuai dengan teori Anonim (2011) bahwa salah satu hal yang harus dipeerhatikan dalam penilaian proyek adalah kesesuaian dengan mata pelajaran, dengan mempetimbangkan tahap pengetahuan, pemahaman dan keterampilan dalam pembelajaran.

2. Uji coba hanya dilaksanakan di satu kelas saja, di mana setiap kelas memiliki karakteristik mahasiswa yang berbeda sehingga kemungkinan penggunaan perangkat assesmen autentik ini belum tentu menghasilkan dampak yang sama.

3. Keterbatasan waktu penelitian sehingga fase implementasi hanya dilaksanakan dengan soasialisasi dengan dosen matakuliah berjalan.

\section{Kesimpulan}

Setelah melalui prosedur prosedur pengembangan perangka pembelajaran yang elah dilakukan dengan menggunakan model Plomp serta berdasarkan data hasil pengembangan dan pembahasan yang telah diuraikan, maka dapat disimpulkan bahwa Pengembangan perangkat assesmen autentik dengan muenggunakan model Plomp yang terdiri dari 5 fase yaitu 1) fase awal; 2) fase perancangan; 3) fase kontruksi; 4) fase tes dan evaluasi; 5) fase implementasi dihasilkan perangkat penilaian yang: Valid yang dibuktikan dengan adanya koefisien korelasi dari perangkat penilaian kognitif, penilaian psikomotorik, dan penilaian afektif lebih besar dari 0,35 dan nilai signifikansi lebih kecil dari taraf signifikansi 5\%. Reliabel, berdasarkan hasil uji reliabilitas secara empirik dengan menggunakan rumus Alpha Cronbach diperoleh nilai koefisien korelasi perangkat 
p-ISSN 2621-5527

e-ISSN 2621-5535
Pengembangan Assesmen Autentik Berbasis Proyek pada Mata Kuliah Biologi Terapan Melalui Model Pembelajaran Kooperatif Tipe Group Investigation

(hIm. 88-100)

penilaian kognitif, penilaian psikomotorik, dan penilaian afektif secara keseluruhan lebih besar dari 0,70. Objektif, analisis uji objektifitas dengan menggunakan rumus ANAVA terhadap perangkat penilaian kognitif, penilaian psikomotorik, dan penilaian afektif secara keseluruhan diperoleh hasil signifikansi dari observer lebih besar dari taraf signifikansi 5\% yang berarti bahwa tidak terjadi variasi penilaian yang dilakukan oleh ketiga observer. Praktis, analisis uji coba kepraktisan perangkat assesmen autentik memiliki kevalidan 4,05 dengan kategori sangat valid. Sedangkan pada data hasil pengamatan para observer didapatkan nilai keterlaksanaan $\left(\mathrm{T}_{\mathrm{L}}\right)$ sebesar 3,64 dengan kategori sebagian besar terlaksana.

\section{Referensi}

Huda, M. (2011). Cooperative Learning, Metode, Teknik, struktur dan model penerapan. Jakarta, Pustaka Pelajar.

Johnson, E, B. (2007). Contextual Teaching and Learning, Menjadikan Kegiatan Belajar Mengajar Mengasyikkan dan Bermakna. Bandung: Mizan Learning Center (MLC).

Marisi, A, K. (2007). Jurnal Penelitian dan Evaluasi Pendidikan Efektivitas, Model Pengukuran Kreativitas dalam Pembelajaran Hemispherekanan (HK) untuk Meningkatkan Kreativitas Mahasiswa Kelas V dalam mata Pelajaran IPA.Vol. 2.Yogyakarta: HEPI, PPs Universitas Negeri Yogyakarta.

Muslich, M. (2010). Authentic Assessment: Penilaian Berbasis Kelas dan Kompetensi. Bandung, Refika Aditama.

Novianty, Rina. (2012). Pengembangan Perangkat Penilaian Kinerja Materi Pokok Larutan Penyangga. Tesis. Tidak diterbitkan. Makassar: Program Pacasarjana Universitas Negeri Makassar.

Ovianti, M.S. (2013). Pengembangan Instrumen Penilaian Autentik pada Proses dan Hasil Pembelajaran Matematika Materi Persamaan Garis Lurus di Kelas VIII SMP Berdasarkan Standar KTSP. Jambi, P-MIPA FKIP Universitas Jambi.

Rahayu, T., Purwoko \& Zulkardi. (2008). Pengembangan Instrumen Penilaian dalam Pendidikan Matematika Realistik Indonesia (PMRI) di SMPN 17 Palembang. Jurnal Pendidikan Matematika, (Online), 2 (2).

Ruslan. (2009). Prinsip Dasar Evaluasi. Makassar : Disampaikan pada Diklat Guru Sekolah Dasar Mata Pelajaran Matematika. Lembaga Penjamin Mutu Pendidikan Sulawesi Selatan.

Slavin, R, E. (2008). Cooperative Learning. Bandung: Nusa Media.

Uno, H., \& Koni, S. (2012). Assesmen Pembelajaran. Jakarta: Bumi Aksara.

Wiyarsih, A. \& Priyambodo, E. (2011). Efektivitas Penerapan Penilaian Proyek (Project Based Assessment) pada Pembelajaran Kimia Terhadap Kemampuan berfikir dan Ketuntasan Belajar Kimia Mahasiswa SMA di Sleman. Prosiding Seminar Nasional Kimia. Surabaya: Unesa. 
100 Jurnal Biology Teaching and Learning, Volume 1, Nomor 2, Desember 2018

Pengembangan Assesmen Autentik Berbasis Proyek pada Mata Kuliah Biologi

Terapan Melalui Model Pembelajaran Kooperatif Tipe Group Investigation

p-ISSN 2621-5527

(hlm. 88-100)

e-ISSN2621-5535

Sri Mukminati Nur $\quad$ S.Pd, M.Pd. STKIP Pembangunan Indonesia Makassar.

Email: srimukminati07@gmail.com

Yusniar Rasjid

S.Pd, M.Pd. STKIP Pembangunan Indonesia Makassar

Email: yusniar.rasjid@gmail.com 